\title{
THE DESIGN OF COCONUT MATURITY PREDICTION DEVICE WITH ACOUSTIC FREQUENCY DETECTION USING NAIVE BAYES METHOD BASED MICROCONTROLLER
}

\author{
Diana Rahmawati, Haryanto, Fahrus Sakariya,
}

\begin{abstract}
The level of coconut maturity can be determined by not only observing its shell color but also by applying audio recognition approach from knocking on coconut shell. This knocking sound distinguishes young, fairly mature, and mature coconut. Recognizing the sound characteristic of knocking on coconut is usually performed by the skilled ones who are having extensive experiences and sound sensitiveness of coconut knocking. In order to substitute the skilled ones, the design of coconut maturity prediction device with acoustic frequency detection is invented. The coconut sound signal is tapped by stethoscope which is connected to MAX9814 noise sensor. Arduino Due micro-controller is used to process the signal. The process in processing the signal consists of: conversing analog signal to digital, screening the signal, and finding the average value of sound signal frequency spectrum. The signal screening uses bandpass digital filter, type IIR (Infinite Impulse Response) Elliptic order 7. This filter is utilized in order that the signal that is being processed is not some noise but the signal of knocking sound on coconut. The calculation of average value of sound signal frequency spectrum uses FFT (Fast Fourier Transform) analysis. The maturity prediction is carried out using the classification method of Naive Bayes. The input is three average value of knocking sound frequency and coconut size, and the output is classification of coconut maturity. From this research, it is generated $80 \%$ of system success rate.
\end{abstract}

Keywords-Coconut, IIR elliptic filter, Naive Bayes, MAX9814 sensor.

\section{INTRODUCTION}

O oconut is a fruit that is widely available all around Indonesia. Coconut maturity cannot be determined solely by judging its color and size. Coconut shell color

Diana Rahmawati, Dosen di Jurusan Teknik Elektro Universitas Trunojoyo Madura, Bangkalan, Indonesia (+62 8523162 4828; email diana_rahmawti@yahoo.com)

Haryanto, Dosen di Jurusan Teknik Elektro Universitas Trunojoyo Madura, Bangkalan, Indonesia (+62 $821 \quad 4098$ 7194; email haryanto_utm@yahoo.com)

Fahrus Sakariya, Mahasiswa di Jurusan Teknik Elektro Universitas Trunojoyo Madura, Bangkalan, Indonesia (+62 8523457 7356; email fahrussakariya@gmail.com) depends on its variety, temperature, and geographical location where the coconut tree grows. Traditionally, the farmers and coconut sellers determine coconut maturity by listening intensively from the sound produced by knocking on coconut shell. According to Widhi Afiatun Nafi'ah cs (2015), the maturity level of coconut is going to affect acoustic frequency produced by knocking on coconut shell. This is because the more mature coconut is, the thicker and harder coconut meat is going to be and the coconut shell is going to be harder as well. Other than the previous statement, coconut water is going to lessen, with the result that coconut weight is going to get lighter which causes the improvement in the frequency of knocking sound on coconut. This research is performed by tapping the knocking sound on coconut using a voice recorder, then processing that particular sound in spectra PLUS-DT software to analyze that frequency dispersion. The purpose is to find the average value of frequency spectrum that occurs [1].

The application of acoustic frequency is also to detect the maturity level of other fruit such as melon by analyzing acoustic impulse response that fruit [2], and watermelon by using Mel-Frequency Cepstrum Coefficients (MFCC) [3]. As an addition to previous point, acoustic frequency which is produced from sound tapping over knocking sound on fruit is able to determine content quality of fruit, as an experiment that is performed on brinjal (sort of eggplant variety) with a technique of non-destructive method [4] and on watermelon with MFCC technique [5]. In the most current research, the instrument that is applied in tapping the fruit acoustic signal does not use noise sensor but Acoustic Vibration Technology (AVT) or some sort of technology based vibration sensor (piezoelectric) [6].

\section{RESEARCH METHOD}

\section{A. Coconut (Cocos Nuficera L.)}

Coconut or cocos nuficera $l$. is an endemic fruit growing in tropical islands that tastes wonderful and fresh. Coconut meat contains many beneficial traits for human health. The life stage of coconut affects the 
content of beneficial substances for human health that are stored either in its meat or water. The older coconut is, the higher acoustic frequency of coconut knocking sound is going to be [1].

Generally, there are three classes of coconut, they are; dwarf coconut, tall coconut, and hybrid coconut [7].

The demand for coconut is exceptionally high. In 2016, Indonesia has exported coconut in total of 1.123 .392 ton for $\$ 843.165 .000$ and imported in total of 4.226 ton for $\$ 4.376 .000$ [8].

\section{B. Naive Bayes. Classification}

Naive Bayes is a classification prediction technique and a simple detection and it is easy to apply algorithm in its system. One of the examples of this method's benefit is it is able to detect spam in texts base digital [9] and heart abnormalities in biomedical sector [10]. Naive Bayes classification method has a strong independence (naive). The model used in Naive Bayes model is in a form of independent feature which means all of the features can be unrelated with the absence or presence of a feature in the same data [11]. Generally, classification formulation uses a probability approach which is broken down in the equation 1 .

$$
P(Y \mid X)=\frac{P(Y) \Pi_{i=1}^{q} P\left(X_{i} \mid Y\right)}{P(X)}
$$

$\mathrm{P}(\mathrm{Y} \mid \mathrm{X})$ is a data probability with factor $\mathrm{X}$ and class $\mathrm{Y}, \mathrm{P}(\mathrm{Y})$ is an initial probability of class $\mathrm{Y}, \Pi_{\mathrm{i}=1}^{\mathrm{q}} \mathrm{P}\left(\mathrm{X}_{\mathrm{i}} \mid \mathrm{Y}\right)$ is an independent probability of class $\mathrm{Y}$ in all features within vector $\mathrm{X}$ also it is an influence of all data features to every of its classes, and $\mathrm{P}(\mathrm{X})$ is a probability value of factor $\mathrm{X}$ which has a fix value to prediction equation.

If the data is in a form of numeric data just like the average value of coconut knocking sound frequency, then Gaussian dispersion technique is needed to be applied in order to generate its probability value.

$$
P\left(X_{i}=x_{i} \mid Y=y_{j}\right)=\frac{1}{\sqrt{2 \pi \sigma_{i j}}} \exp ^{-\frac{\left(x_{i}-\mu_{i j}\right)^{2}}{2 \sigma_{i j}^{2}}}
$$

$\mu_{i j}$ is an average value from sample $\mathrm{Xi}(\bar{x})$ from all training data of frequency average from coconut knocking sound which belongs to class $y_{j} . \sigma_{i j}^{2}$ is generated from variant estimation of sample $\left(\mathrm{s}^{2}\right)$ from all of the data training.

\section{Fast Fourier Transform (FFT)}

Fast Fourier Transform is transformation development to Discreet Fourier Transform (DFT) with a purpose to improve the speed in discreet data and turn it into fourier row. Fourier transformation is a mathematical method to transform discreet data signal, which is in discreet time domain, into discreet frequency domain [12]. In the event that the total of complex multiplication in DFT is in the amount of $\mathrm{N}^{2}$ with $\mathrm{N}$ is the original point of fourier transformation sample and for DFT i (N/2), while for FFT, the total of complex multiplication is $(\mathrm{N} / 2) \log _{2}(\mathrm{~N})$. Therefore, the multiplication total is far less than DFT which cause shorter times in computation process.

\section{Noise Sensor; MAX9814 Microphone}

Microphone MAX9814 is a noise sensor that possess advantage in gain control over automatic analog noise (automatic gain control). MAX9814 is working within voltage range of $2,7-5,5 \mathrm{~V}$ with current of $3 \mathrm{~mA}$. The output from the amplifier is about $2 \mathrm{Vpp}$ max on a $1.2 \mathrm{~V}$ DC bias. MAX9814 is able to tap or respond on audio with frequency of $20 \mathrm{~Hz}-20 \mathrm{KHz}$ and as reference density of low noise input in the amount of $30 \mathrm{nV} / \sqrt{\mathrm{Hz}}$ [16].

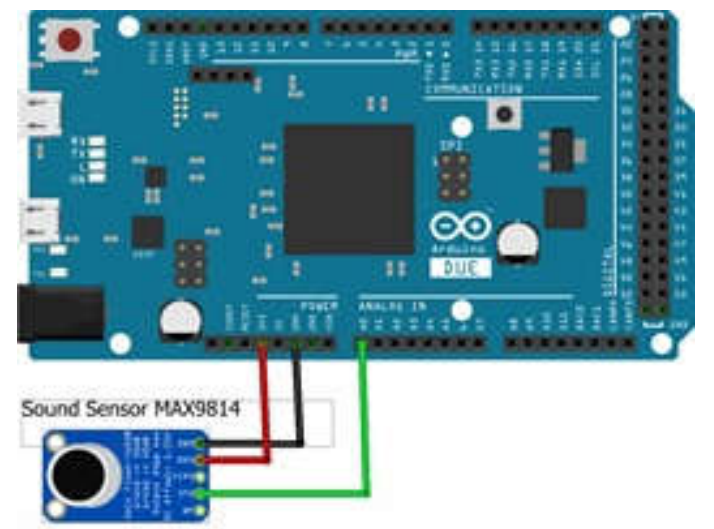

Figure 1. The Schematic of MAX9814 Sound Sensor Module with Arduino Due

\section{E. Digital Filter}

The usage of digital filter has a purpose to minimize or completely omit frequency magnitude of noise signal from the digital signal of analog signal sampling result. The processed signal is the original signal from sampling process with the result that the obtained outcome is in the form of good digital signal data with less noise. In most cases, digital filter consists of four types of filter; lowpass, highpass, bandpass, and bandstop filter. While the types for digital filter are FIR (Finite Impulse Response) and IIR (Infinite Impulse Response). One of methods of FIR is windowing method which has several types depending on maximum value of filter design stopband attenuation, one of them is rectangular, hanning, hamming, blackman, and kaiser. In general, FIR filter equatioin is broken down in third equation below [17].

$$
y[n]=\sum_{k=0}^{N-1} h[k] x[n-k]
$$

IIR filter method has a capability to use BZT (Bilinear Z-Transform) method with analog filter which possesses three types; butterworth, chebyshev, and elliptic. The common equation for IIR filter is broken down into the following fourth equation.

$$
y[n]=\sum_{k=0}^{N} b_{k} x[n-k]-\sum_{k=1}^{M} a_{k} y[n-k]
$$

$y[n]$ is filter output, $x[\mathrm{in}]$ is digital signal input, and $\mathrm{N}$ in FIR is the filter length, while $\mathrm{N}$ in IIR is the filter length in input, and $M$ is the length filter in feedback output.

There are two types of digital filter design that are being fashioned in this research in the sound signal processing system. They are FIR digital filter blackman 
type and IIR elliptic type. The filter has passband frequency from 60 to $300 \mathrm{~Hz}$, stopband frequency from 50 to $320 \mathrm{~Hz}$, stopband attenuation of $40 \mathrm{DB}$, ripple passband of $0,1 \mathrm{DB}$. Both designs that has been constructed later on are going to be compared in order to figure out whether the outcome for frequency respond is good or bad. The next step is the best filter is going to be selected to be implemented in the system. The frequency sample is $1,000 \mathrm{~Hz}$ since the frequency of coconut knocking from young to mature coconut is in average of $65 \mathrm{~Hz}-165 \mathrm{~Hz}$. This is generated from the $5^{\text {th }}$ equation [14] to meet Nyquist criteria of engineer version.

$$
F_{s} \geq 2,2 f_{\max }
$$

\section{F. Design System of Coconut Maturity Prediction}

The designed system is applied to detect and tap on sound signal from the process of coconut knocking. The produced sound is caught by MAX9814 noise sensor which is connected to stethoscope diaphragm, then that sound signal is processed in micro-controller. The signal processing aims to reduce some noises in digital sound signal by using digital filter and to obtain the average on frequency dispersion of coconut knocking sound. The average value of knocking sound frequency resulted from the training then is saved in SD (Secure Digital) memory. This value is used as training data for trial test of coconut maturity prediction by applying acoustic frequency detector with Naive Bayes method. In most cases, the diagram block of system is illustrated as in Image 2, system description is illustrated as in Image 3, and system hardware is designed as in Image 4.

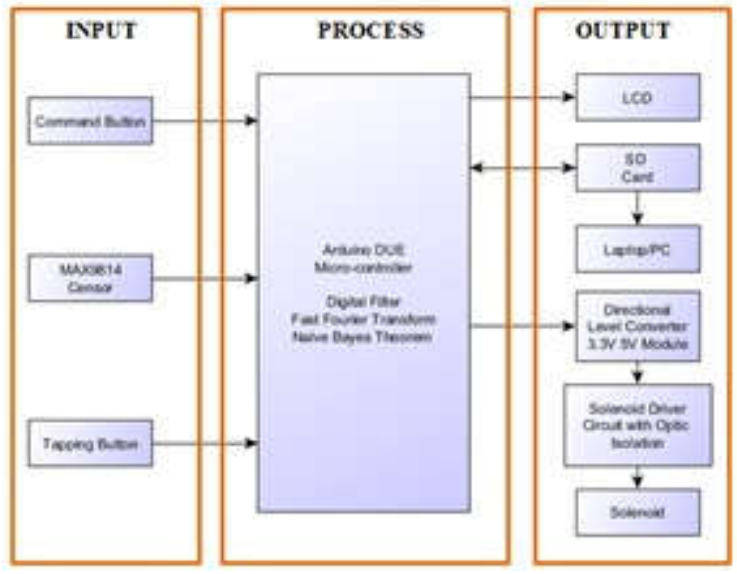

Figure 2. System Diagram Block

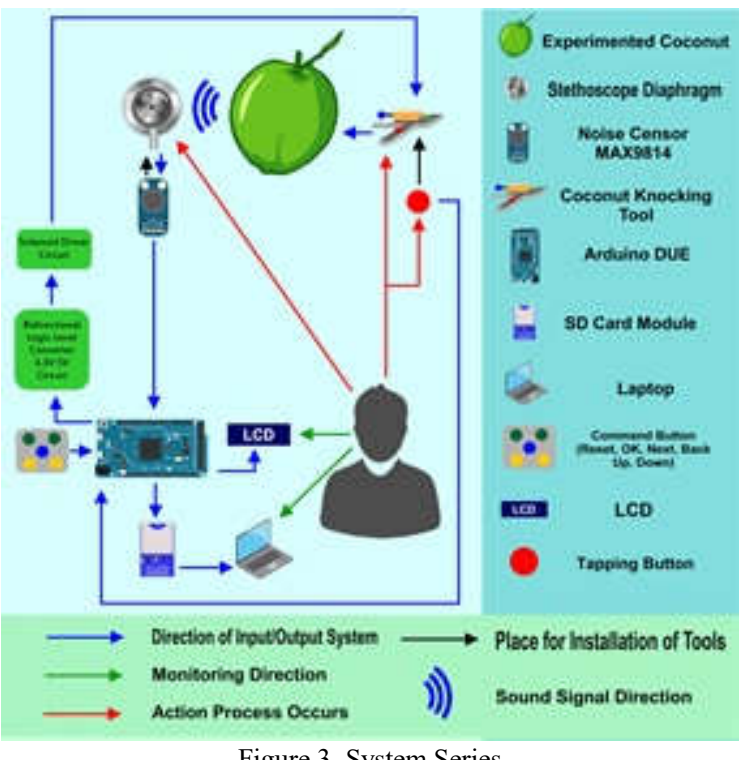

Figure 3. System Series

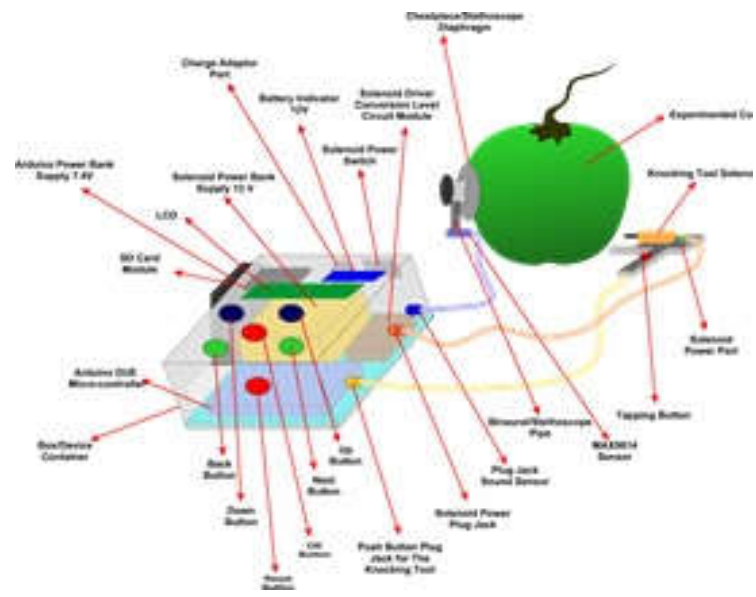

Figure 4. Device Design

\section{RESULT AND ANALYSIS}

\section{A. Digital Bandpass Filter Testing}

The result of calculation is used to design bandpass FIR filter of windowing blackman type. From this process, it is generated that the filter length is an odd number which is $\mathrm{N}=367$. For the design of second filter, it uses elliptic IIR filter. From this, it is generated that the filter order is $N=7$. As for the conclusion, filter coefficient has 15 coefficient for the input and 14 coefficien for the feedback output. The coefficient values of IIR filter is broken down in Table 1 and 2

TABLE I

\begin{tabular}{c|cccc}
\multicolumn{5}{l}{ INPUT COEFFICIENT OF BANDPASS IIR BZT ELLIPTIC DIGITAL FILTER } \\
\hline \hline$k$
\end{tabular}

\begin{tabular}{l|llllll}
$b_{k}$ & 0,0373 & $-0,0973$ & 0,0432 & $-0,0028$ & 0,1553 \\
\hline$k$ & 5 & 6 & 7 & 8 & 9 \\
$b_{k}$ & $-0,1162$ & $-0,1146$ & 0 & 0,1146 & 0,1162 \\
\hline$k$ & 10 & 11 & 12 & 13 & 14 \\
$b_{k}$ & $-0,1553$ & 0,0028 & $-0,0432$ & 0,0973 & $-0,0373$ \\
\hline \hline
\end{tabular}
$k=0,1,2, \ldots, \mathrm{k}$ is series of filter coefficient array values 
TABLE II

FEEDBACK OUTPUT COEFFICIENT OF BANDPASS IIR BZT ELLIPTIC DIGITAL FILTER

\begin{tabular}{l|lllll}
\hline \hline$k$ & 1 & 2 & 3 & 4 & 5 \\
$a_{k}$ & $-4,9954$ & 12,8796 & $-23,8327$ & 35,9363 & $-45,4870$ \\
\hline$k$ & 6 & 7 & 8 & 9 & 10 \\
$a_{k}$ & 48,7738 & $-44,9656$ & 35,8600 & $-24,4570$ & 14,0452 \\
\hline$k$ & 11 & 12 & 13 & 14 & \\
$a_{k}$ & $-6,6540$ & 2,4811 & $-0,6516$ & 0,0931 & \\
\hline \hline
\end{tabular}

$a_{k}$ is digital filter coefficient for feedback output of filtered discreet signal with $k=0,1,2, \ldots, \mathrm{k}$ is series of filter coefficient array values

The next step is comparing the results between the first and second filter from the respond graphic of frequency function transfer by using MATLAB. MATLAB simulation is applied to calculate the value of frequency function transfer from the obtained filter coefficient equation and to create graphics with plot features in the softwares. From the test result, it is generated that the filter is going to be applied is bandpass IIR BZT elliptic filter. This filter is chosen, other than because it has better frequency respond than the one of blackman FIR digital causal filter, it is because it possesses advantage of a small filter order with a result that the total of filter coefficient is also small that the system process is more efficient. That coefficient value is implemented within microcontroller processor and used in processing the signal of coconut knocking sound.

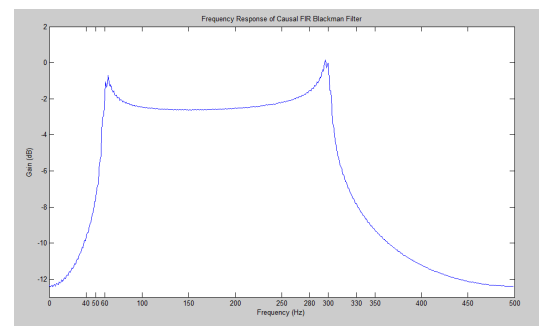

Figure 5. Causal Filter Frequency Respond of Blackman FIR Digital Bandpass with Defined Coefficient in $0 \leq \mathrm{k} \leq \mathrm{N}-1$

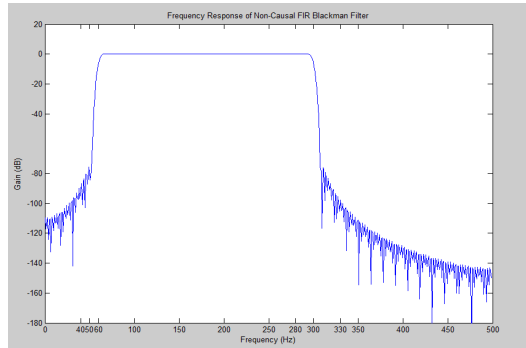

Figure 6. Frequency Response of Bandpass Non-causal Digital Filter of FIR Blackman with Defined Coefficient in- $(\mathrm{N}-1) / 2 \leq \mathrm{k} \leq$ $(\mathrm{N}-1) / 2$

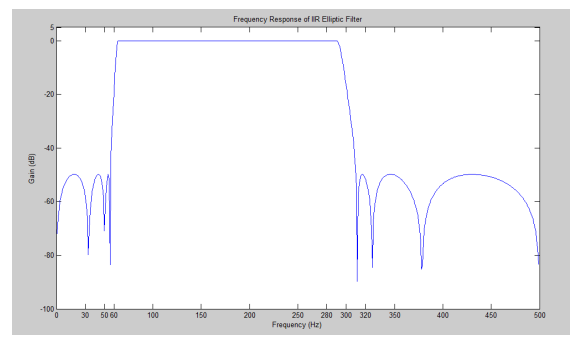

Figure 7. Frequency Response of Bandpass Digital Filter of IIR Elliptic Order 7

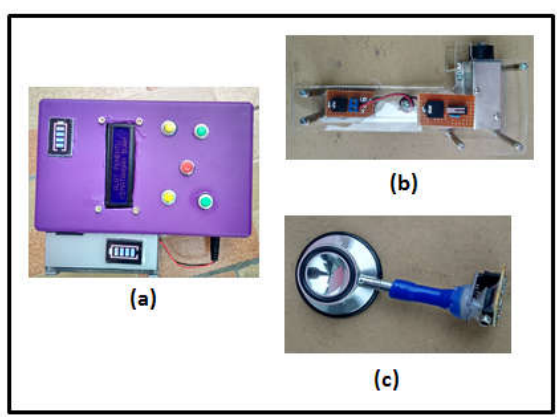

Figure 8. (a) electronic box, (b) knocking tool, and (c) audio tapping device with sensor and stethoscope

\section{B. The Test on Naive Bayes Method in Predicting Coconut Maturity}

The input of Naive Bayes classification method is in a form of three average values of coconut knocking sound which are obtained by three times process of different way of knocking. The frequency average values are obtained from the process of tapping on knocking sound, the processing of digital signal which is performed in Arduino Due that is started from ADC conversion, and the pursuit on frequency spectrum value with FFT. Apart of the average value of frequency, system input is also in a form of the value of coconut size classification which is small, medium, and big.

The tested coconut consists of several varieties, such as green, chocolate or red coconut, genjah salak coconut, genjah gading coconut. The coconut testing covers several stages of different maturity. The young coconut has some characteristics in its meat, starting from no meat to thin and soft meat. Medium coconut (fairly mature) is is marked off with thick meat and its texture is mostly dominated by hard meat to complete domination of it.

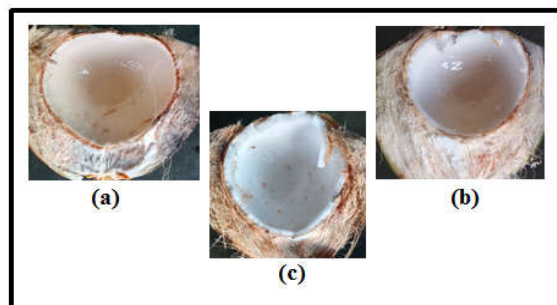

Figure 9. Coconut with different stages of maturity (a) young, (b) fairly mature (degan) and (c) old

The following is data table of results from training and testing for maturity level classification, or coconut age, with Naive Bayes using the device design that has been constructed. 
TABLE III

Training Data of Coconut Maturity LeVel Prediction System

\begin{tabular}{lllllll}
\hline \hline \multirow{2}{*}{ No } & Coconut & \multicolumn{2}{c}{ Frequency Average $(\mathrm{Hz})$} & \multirow{2}{*}{ SZ } & Us \\
& eVariety & \multicolumn{1}{c}{ F1 } & F2 & F3 & & ia \\
\hline 1 & Green & 174.92 & 159.98 & 164.87 & $\mathrm{~S}$ & $\mathrm{M}$ \\
2 & Green & 177.08 & 162.76 & 167.49 & $\mathrm{~S}$ & $\mathrm{M}$ \\
3 & Red & 172.68 & 178.77 & 170.61 & $\mathrm{~S}$ & $\mathrm{D}$ \\
4 & Red & 143.1 & 155.04 & 155.71 & $\mathrm{~S}$ & $\mathrm{M}$ \\
5 & Red & 176.28 & 177.04 & 193.31 & $\mathrm{~S}$ & $\mathrm{D}$ \\
6 & Green & 209.75 & 203.77 & 203.66 & $\mathrm{~B}$ & $\mathrm{~T}$ \\
7 & Green & 174.51 & 166.01 & 168.13 & $\mathrm{~B}$ & $\mathrm{D}$ \\
8 & Green & 179.65 & 187.27 & 180.37 & $\mathrm{~B}$ & $\mathrm{D}$ \\
9 & Green & 204.87 & 200.48 & 193.88 & $\mathrm{~B}$ & $\mathrm{~T}$ \\
10 & Green & 194.11 & 200.69 & 197.6 & $\mathrm{~S}$ & $\mathrm{~T}$ \\
11 & Red & 158.08 & 148.97 & 162.41 & $\mathrm{~B}$ & $\mathrm{M}$ \\
12 & Green & 167.22 & 179.38 & 164.78 & $\mathrm{~B}$ & $\mathrm{D}$ \\
13 & Green & 172.12 & 172.55 & 173.47 & $\mathrm{~B}$ & $\mathrm{D}$ \\
14 & Green & 207.32 & 209.04 & 208.02 & $\mathrm{~S}$ & $\mathrm{~T}$ \\
15 & Genjah Salak & 152.3 & 168.79 & 172.65 & $\mathrm{~K}$ & $\mathrm{M}$ \\
16 & Genjah Salak & 157.35 & 159.83 & 158.75 & $\mathrm{~K}$ & $\mathrm{M}$ \\
17 & Genjah Salak & 184.79 & 165.79 & 176.02 & $\mathrm{~K}$ & $\mathrm{D}$ \\
18 & Genjah Salak & 172.85 & 175.6 & 171.59 & $\mathrm{~K}$ & $\mathrm{D}$ \\
19 & Genjah Salak & 200.01 & 201.86 & 186.65 & $\mathrm{~K}$ & $\mathrm{~T}$ \\
20 & Genjah Salak & 195.2 & 199.4 & 207.38 & $\mathrm{~K}$ & $\mathrm{~T}$ \\
21 & Genjah Salak & 162.75 & 145.94 & 164.65 & $\mathrm{~K}$ & $\mathrm{M}$ \\
22 & Brown & 191.85 & 191.45 & 187.88 & $\mathrm{~B}$ & $\mathrm{~T}$ \\
23 & Brown & 161.67 & 169.72 & 163.61 & $\mathrm{~B}$ & $\mathrm{M}$ \\
24 & Brown & 152.2 & 168.07 & 168.69 & $\mathrm{~B}$ & $\mathrm{M}$ \\
\hline \hline
\end{tabular}

The size classification of coconut testing consists of small size $(\mathrm{K})$ which is identified with round shape and its circumference is small, medium size (S) which is identified with oval-long shape and its circumference is medium, and big size (B) is identified with its big circumference and length. While for coconut maturity level consists of young (M), fairly mature (D), and old (T) coconut.

TABLE IV

The Test Data of Coconut Maturity Level PRediction System

\begin{tabular}{|c|c|c|c|c|c|c|c|}
\hline & & Frequen & Averag & $\mathrm{Hz})$ & & $\mathrm{P}$ & \\
\hline $\begin{array}{l}\text { m } \\
\text { ple }\end{array}$ & $\begin{array}{l}\text { Coconut } \\
\text { Variety }\end{array}$ & F1 & F2 & F3 & $\begin{array}{l}\mathrm{S} \\
\mathrm{i} \\
\mathrm{z} \\
\mathrm{e}\end{array}$ & $\begin{array}{l}\mathrm{d} \\
\mathrm{i} \\
\mathrm{c} \\
\mathrm{t} \\
\mathrm{i} \\
\mathrm{o} \\
\mathrm{n}\end{array}$ & $\begin{array}{l}\text { A } \\
\text { ge }\end{array}$ \\
\hline 1 & Brown & 185.5 & 213.22 & 208.41 & B & $\bar{M}$ & $\mathrm{~T}$ \\
\hline 2 & Brown & 157.64 & 170.6 & 165.6 & B & M & M \\
\hline 3 & Brown & 190.82 & 194.61 & 192.21 & B & D & $\mathrm{T}$ \\
\hline 4 & Brown & 163.24 & 167.76 & 173.53 & B & M & M \\
\hline 5 & Brown & 191.68 & 191.13 & 190.07 & B & D & $\mathrm{T}$ \\
\hline 6 & Brown & 165.62 & 163.52 & 163.76 & B & $\mathrm{T}$ & M \\
\hline 7 & Green & 168.03 & 173.83 & 170.3 & B & D & D \\
\hline 8 & Brown & 158.65 & 158.8 & 154.82 & B & D & M \\
\hline 9 & Brown & 199.92 & 183.72 & 192.94 & B & $\mathrm{T}$ & $\mathrm{T}$ \\
\hline 10 & Gading & 158.41 & 150.77 & 145.35 & B & $\mathrm{T}$ & $\mathrm{T}$ \\
\hline 11 & Gading & 165.79 & 140.88 & 162.87 & $\mathrm{~S}$ & M & $\mathrm{T}$ \\
\hline 12 & Green & 173.11 & 178.27 & 181.33 & $\mathrm{~S}$ & D & D \\
\hline 13 & Green & 197.81 & 189.23 & 207.68 & B & D & $\mathrm{T}$ \\
\hline 14 & Green & 163.64 & 163.3 & 160.42 & $\mathrm{~S}$ & $\mathrm{~T}$ & M \\
\hline 15 & Green & 174.4 & 179.35 & 184.15 & $\mathrm{~S}$ & M & D \\
\hline 16 & Genjah Salak & 177.41 & 180.44 & 182.44 & K & M & M \\
\hline 17 & Genjah Salak & 166.53 & 154.61 & 158.94 & K & D & M \\
\hline 18 & Genjah Salak & 180.86 & 181.28 & 170.09 & K & D & M \\
\hline 19 & Genjah Salak & 168.75 & 156.46 & 171.49 & K & $\mathrm{T}$ & M \\
\hline 20 & Green & 205.45 & 205.76 & 197.96 & B & & $\mathrm{T}$ \\
\hline \multicolumn{5}{|c|}{ Success Rate } & \multicolumn{3}{|c|}{$80 \%$} \\
\hline
\end{tabular}

SZ is a size classification from coconut testing which consists of small size $(\mathrm{K})$ which is identified with round shape and its circumference is small, medium size (S) which is identified with ovallong shape and its circumference is medium, and big size (B) is identified with its big circumference and length. While for coconut maturity level consists of young (M), fairly mature (D), and old (T) coconut.
From the test result with application of 24 coconut training sample data and 20 coconut test sample data in which contain different coconut maturity level, varieties, and size. It is generated the success rate of $80 \%$ from the conducted test.

$\%$ Success $=\frac{\text { Total of experiment }- \text { failed experiment }}{\text { Total of experiment }} \times 100 \%$

\section{CONCLUSIONS}

The conclusions from this conducted research are described in several points below:

- The digital filter that is used to process the sound signal of coconut knocking that micro-controller based is bandpass digital filter of IIR elliptic type. The reason is because its efficiency and frequency response is much better than bandpass digital filter of FIR blackman type.

- From the test that is applying Naive Bayes method, it is generated the success rate of system test for $80 \%$ from total of 20 test sample with 24 training data sample.

Suggestions for the further research are:

- To add series of analog filter in order that the obtained frequency data of coconut knocking sound signal is more accurate and eschewed from noise signal which is not produced by fruit knocking sound.

- To use VAD (Voice Activity Detection) to simplify sound selection when tapping process is in progress in order that the entire processed sound signal range is the sound from the coconut knocking and the tapped noise is getting less and less.

- To apply other classification and digital signal extraction method in order that the coconut classification category is not solely limited to its maturity level but also is able to predict how much the water content inside, the meat thickness, and the husk thickness of coconut. By figuring out those factors, one is able to predict the volume of coconut itself.

\section{REFERENCE}

[1] Nafi'ah, A., dan Mitrayana. "Deteksi Frekuensi Akustik pada Buah Kelapa Magelang (Cocos nucifera) Menggunakan Software Spectra PLUS-DT”. Universitas Gajah Mada. Jurnal Fisika Indonesia Vol. 19 No.57 Hal. 51-54. 2015.

[2] Kusumaliski, N. "Pengembangan Metode Deteksi Kematangan Melon (Cucumis melo L.) dengan Respon Impuls Akustik”. Institut Pertanian Bogor. (Skripsi). 2015.

[3] Aziz A., M. "Deteksi Kematangan Buah Semangka dengan Deteksi Suara Menggunakan Metode Mel-Frequency Cepstrum Coefficient (MFCC)". Universitas Nusantara PGRI Kediri. Simki-Techsain Vol.01 No.07. 2017.

[4] Karthickumar, P., dkk. "Acoustic Resonance Technique: A Promising Non-Destructive Method for Detecting the Internal Quality of Brinjal". Indian Institute of Crop Processing Technology. Research Journal of Agricultural Sciences Vol.5 No.4 p.735-737. July-August 2014.

[5] Phoophuangpairoj, R. "Automated Classification of Watermelon Quality Using Non-flicking Reduction and HMM Squences Deriver from Flicking Sound Characteristics". 
Journal of Information Science and Engineering 30 p.10151033. 2014

[6] Nishani, S., dkk. "Use of Acoustics as Non-Destructive Techniques: A Review". Indian Agricultural Research Institute. International Journal of Current Microbiology and Applied Sciences Vol.6 No.6. 2017.

[7] Mardiatmoko, G., dan Ariyanti, M. (nd) "Produksi Tanaman Kelapa (Cocos nucifera L.)". Badan Penerbit Fakultas Pertanian: Universitas Pattimura.

[8] Hendaryati, D. D., dkk. 2016. "Statistik Perkebunan Indonesia 2015-2017”. Kementerian Pertanian Republik Indonesia. Sekretariat Direktorat Jenderal Perkebunan.

[9] Pooja, dan Bhatia, K. K. "Spam Detection Using Naive Bayes Classifier". YMCA University of Science and Technology. International Journal of Computer Sciences and Engineering Vol.6 Issue 7. July 2018.

[10] Vembandasamy, K., dkk. "Heart Diseases Detection Using Naive Bayes Algorithm". PSG College of Arts and Science. International Journal of Innovative Science, Engineering and Technology Vol.2 Issue 9. September 2015.

[11] Prasetyo, E. 2012. "Data Mining: Konsep dan Aplikasi Menggunakan MATLAB". Yogyakarta: Penerbit ANDI.

[12] Lopez-Caudana, E., dkk. "Classification of Materials by Acoustic Signal Processing in Real Time for NAO Robots". ITESM Campus Ciudad de México. International Journal of Advanced Robotic Systems. July—August 2017.

[13] Hibare, R., and Vibhute, A. "Feature Extraction Techniques in Speech Processing: A Survey". Brahmdevdada Mane Institute of Technology. International Journal of Computer Applications Vol.107 No.5. December 2014.

[14] Zhi-Qiang, Z., dan Li-Ming, Y. "Design of Embedded Speech Recognition System". Shanghai University of Engineering Science. American International Journal of Contemporary Research Vol.7 No.2. June 2017.

[15] Arduino. (2018, Januari 22). Datasheet Arduino Due [Online]. Available: https://hackadaycom.files.wordpress.com/2012/10/due.pdf.

[16] Ada. L. (2018, Oktober 01). Adafruit AGC Electret Microphone Amplifier-MAX9814 Data Sheet [Online]. Available: $\quad$ https://cdnlearn.adafruit.com/downloads/pdf/adafruit-agc-electretmicrophone-amplifier-max9814.pdf.

[17] Gunawan, D., dan Juwono, F. H. 2012. "Pengolahan Sinyal Digital dengan Pemrograman Matlab". Yogyakarta: Graha Ilmu.

[18] Rorabaugh, C. B. 1993. "Digital Filter Designer's Handbook Featuring C Routines". (Buku elektronik). Europe: McGrawHill Education. 